\title{
Synthesis of ${ }^{13} \mathrm{C}$ - and ${ }^{14} \mathrm{C}$-labeled dinucleotide mRNA cap analogues for structural and biochemical studies
}

\author{
Karolina Piecyk ${ }^{a}$, Richard E. Davis ${ }^{b}$, and Marzena Jankowska-Anyszkaa, ${ }^{\text {* }}$ \\ aFaculty of Chemistry, University of Warsaw, Pasteura 1, 02-093 Warsaw, Poland bepartment of \\ Biochemistry and Molecular Genetics, University of Colorado, School of Medicine, Aurora, CO \\ 80045, USA
}

\begin{abstract}
Herein we describe the first simple and short method for specific labeling of mono- and trimethylated dinucleotide mRNA cap analogues with ${ }^{13} \mathrm{C}$ and ${ }^{14} \mathrm{C}$ isotopes. The labels were introduced within the cap structures either at the N7 for monomethylguanosine cap or N7 and N2 position for trimethylguanosine cap. The compounds designed for structural and biochemical studies will be useful tools for better understanding the role of the mRNA cap structures in premRNA splicing, nucleocytoplasmic transport, translation initiation and mRNA degradation.
\end{abstract}

\section{Keywords}

Cap analogue; TMG cap; ${ }^{13} \mathrm{C}$ label; ${ }^{14} \mathrm{C}$ label; mRNA

\begin{abstract}
Gene expression in eukaryotes is a complex process that involves several steps and requires numerous protein factors. One common RNA element involved in mRNA splicing, export, translation, and stability is the unusual structure at the 5 ' end of mRNA known as a 'cap'. ${ }^{1}$ This unique structure consist of 7-methylguanosine linked via a $5^{\prime}, 5^{\prime}$-triphosphate bridge to the first transcribed nucleotide (MMG cap). For many years, numerous studies have been conducted to describe the molecular mechanism of the interaction of the cap with eukaryotic initiation factor $4 \mathrm{E}$ (eIF4E) that is a key step in translation initiation. Structural requirements for the cap-eIF4E interaction were elucidated by biophysical and biochemical methods involving several chemically prepared cap analogues and subsequently confirmed and further defined by multidimensional nuclear magnetic resonance and X-ray crystallography. ${ }^{2}$ In some cases, for example in nematodes such as Caenorhabditis elegans and Ascaris suum, in addition to regular MMG cap, an atypical hypermethylated form of the cap, with two additional methyl groups at the $\mathrm{N} 2$ position of 7-methylguanosine, is present (TMG cap). ${ }^{3}$ This cap is added to the $5^{\prime}$ end of a large percentage of mRNAs by RNA transsplicing of a short 22-nt spliced leader sequence (SL). ${ }^{4}$ In general, eIF4E proteins from higher eukaryotes are unable to effectively recognize and bind the TMG cap. ${ }^{2 \mathrm{~d}, 5}$ However, nematodes efficiently translate TMG-capped mRNAs. ${ }^{3 b, 6}$ Identification and exploration of five eIF4E isoforms in C. elegans provided evidence that the 4E isoforms vary in their ability to distinguish between MMG and TMG caps suggesting that eIF4E of these organisms may differ from that of other species. ${ }^{7}$ Apart from three $C$. elegans isoforms (IFE-1, -2, -5) which are able to bind MMG and TMG caps, other eIF4E orthologs recognizing the two mRNA caps have been described, for example Ascaris suum eIF4E-3 ${ }^{\text {ta }}$
\end{abstract}

(C) 2012 Elsevier Ltd. All rights reserved.

*Corresponding author. Tel.: +48 22822 0211; fax: +48 22822 5996. marzena@ chem.uw.edu.pl. . 
and the sole Schistosoma mansoni eIF4E isoform. ${ }^{8}$ Biochemical, biophysical, theoretical, and structural data are available for different 4 E proteins $\left(C\right.$. elegans, ${ }^{9} A$. suum, ${ }^{6 a}, 10 S$. mansoni ${ }^{8}$ murine ${ }^{11}$ ). Based on these data, models for binding the two caps have been proposed. ${ }^{6 a, 8-11}$ Recently the first crystal structure of Ascaris eIF4E-3 in complex with MMG and TMG cap has been published. ${ }^{10}$ While the data indicate how Ascaris eIFE-3 interacts with the MMG and TMG cap, the exact coherent molecular mechanism describing the interaction of other isoforms binding either cap is not completely understood.

Herein we describe the synthesis of ${ }^{13} \mathrm{C}$ and ${ }^{14} \mathrm{C}$ labeled mono- and trimethylated cap analogues as tools that will facilitate analysis of the specificity of nematode eIF4E isoforms for the MMG and TMG caps and help to examine proteins interactions with the two caps in a more detailed way.

A well-defined synthetic pathway to prepare dinucleotide cap analogues involves obtaining imidazolide derivative of one nucleotide in a reaction with $2,2^{\prime}$-ditiopyridine and triphenylphosphine prior to coupling with a second nucleotide in the presence of an excess of double-charged ions (such as $\mathrm{Zn}^{2+}$ or $\mathrm{Mn}^{2+}$ ) in anhydrous or aqueous condition. ${ }^{12}$

Nevertheless, for the synthesis of ${ }^{13} \mathrm{C} /{ }^{14} \mathrm{C}$ MMG and TMG caps, the procedure needed to be modified to minimize the number of steps with the radioactive materials and due to the cost of isotopically labeled substrates $\left({ }^{13} \mathrm{C}\right.$ or ${ }^{14} \mathrm{C}$ methyl iodide). Our method to synthesize the MMG dinucleotide cap analogues labeled with either ${ }^{13} \mathrm{C}$ or ${ }^{14} \mathrm{C}$ was accomplished (Scheme 1) by direct methylation of the dinucleotide GpppG that was prepared by coupling of guanosine $5^{\prime}$-diphosphate (GDP) with an imidazolide derivative of guanosine $5^{\prime}$ monophosphate (imGMP). ${ }^{13}$ As GpppG is symmetric and can be methylated on both guanine residues, the procedure was optimized and evaluated using unlabeled methyl iodide and numerous reaction conditions (variation of reaction time, excess of methyl iodide, temperature) and HPLC (data not shown) to define conditions that prevent over methylation. The best results were obtained with twofold molar excess of ${ }^{13} \mathrm{CH}_{3} \mathrm{I}$ (Sigma-Aldrich) or ${ }^{14} \mathrm{CH}_{3} \mathrm{I}$ (ViTrax) at room temperature. ${ }^{14}$ The synthesis of ${ }^{13} \mathrm{C}$ labeled MMG cap has been described previously ${ }^{15}$ but it was achieved by a longer two-step procedure.

In contrast to MMG cap, a TMG cap labeled with ${ }^{13} \mathrm{C}$ and ${ }^{14} \mathrm{C}$ isotopes required a multistep procedure (Scheme 2). To our knowledge this is the first report of such a synthesis. The first step required transformation of guanosine to the corresponding $2^{\prime}, 3^{\prime}, 5^{\prime}$ - $O$-acetylguanosine using acetic anhydride $\left(\mathrm{Ac}_{2} \mathrm{O}\right)$ in the presence of triethylamine (TEA) and $\mathrm{N}, \mathrm{N}$ (dimethylamino) pyridine (DMAP). The obtained derivative was further protected at the $\mathrm{O} 6$ position of guanosine using the Mitsunobu reaction with $p$-nitrophenylethanol (NPE) under anhydrous conditions. The product $\mathbf{3}$ was then converted to its 2 -fluoro derivative $\mathbf{3}$ by performing non-aqueous diazotization and fluoridation at low temperature with $t$-butyl nitrite as the diazotizing agent and HF in pyridine as the fluoride source. The purified 2fluoro nucleoside was then treated with a fourfold molar excess of $\left({ }^{13} \mathrm{CH}_{3}\right)_{2} \mathrm{NH}$. As the dimethylamine labeled with ${ }^{13} \mathrm{C}$ carbon can only be obtained as a hydrochloride, a nucleophilic substitution was performed in aqueous solution of $\mathrm{DMSO} / \mathrm{AcCN} / \mathrm{H}_{2} \mathrm{O} / \mathrm{Et}_{3} \mathrm{~N}$ in a temperature-controlled oil bath at $60{ }^{\circ} \mathrm{C}$ until the fluoronucleoside had completely disappeared, as evaluated by TLC analysis. After completion of the substitution reaction, 1,8-diazabicyclo[5.4.0] undec-7-ene (DBU) was added to the reaction mixture to remove the NPE group followed by the addition of a mixture of $0.5 \mathrm{M} \mathrm{NaOH}$ in THF/MeOH/NaOH $/ \mathrm{Nq}_{\text {in }}$ order to complete acetyl deprotection. ${ }^{16}$ The nucleoside (4) was purified on silica gel and then phosphorylated using the Yoshikawa method with phosphorus oxide trichloride in trimethyl phosphate (5) and then methylated with fivefold excess of ${ }^{13} \mathrm{CH}_{3} \mathrm{I}$ in anhydrous DMSO $(\mathbf{6})$. The ${ }^{13} \mathrm{C}$ trimethylated guanosine $5^{\prime}$ - monophosphate was further coupled with the imidazolide derivative of GDP (7) under anhydrous conditions (DMF) in the presence of 
zinc ions. ${ }^{15,17}$ This route was chosen as it is routinely used by us for the preparation of unlabeled TMG cap analogues.

We chose to introduce the carbon-14 labeled methyl group into the N7 position of guanine as this reaction is relatively simple and with only one labeled methyl group in the cap moiety, leads to a relatively high specific activity of the cap. ${ }^{14} \mathrm{C}$ TMG cap was obtained as described for the preparation of ${ }^{13} \mathrm{C}$ labeled TMG cap except that the substitution step leading to $N^{2}, N^{2}$-dimethylguanosine was carried out with unlabeled dimethylamine. All four cap analogues were purified by ion-exchange chromatography on DEAE-Sephadex A-25 $\left(\mathrm{HCO}_{3}{ }^{-}\right.$form $)$, the relevant fractions collected, pooled, and evaporated repeatedly with cold ethanol. The fractions with both high UV absorbance and high specific activity were combined and the final specific activity of ${ }^{14} \mathrm{C}$ labeled cap analogues was determined after lyopilization: 0.82 and $1.44 \mathrm{GBq} / \mathrm{mmol}$ for MMG and TMG cap, respectively. MMG and TMG cap analogues labeled with ${ }^{14} \mathrm{C}$ and ${ }^{13} \mathrm{C}$ isotopes were converted into sodium salts using Dowex 50 WX8 ion-exchange resin. The structure and homogeneity of final products were confirmed by HPLC, mass spectrometry, ${ }^{1} \mathrm{H}$ NMR, ${ }^{31} \mathrm{P}$ NMR and ${ }^{13} \mathrm{C}$ NMR. ${ }^{1} \mathrm{H}$ NMR spectra of ${ }^{13} \mathrm{C}$-labeled MMG and TMG caps revealed no signals corresponding to unlabeled methyl group (Fig. 1). All methyl groups in the spectra were ${ }^{13} \mathrm{CH}_{3}$ observed as a doublet with the expected large coupling constant. ${ }^{13} \mathrm{C}$ labeling of $\mathbf{1}$ and $\mathbf{8}$ was also confirmed by a single-frequency proton decoupled ${ }^{13} \mathrm{C}$ NMR spectra. Extremely strong signals from one (1) or three (8) methyl carbons with appropriate coupling pattern were also observed.

To evaluate the ${ }^{14} \mathrm{C}$ cap analogues in a functional assay, we carried out decapping experiments (Fig. 2) using $A$. suum and $C$. elegans DcpS, the scavenger decapping enzymes. DcpS cleaves mono- as well as trimethylated cap regioselectively between $\beta$ and $\gamma$ phosphates of the $5^{\prime}, 5^{\prime}$-triphosphate bridge to release $\mathrm{m}^{7} \mathrm{GMP}$ or $\mathrm{m}_{3}^{2,2,7} \mathrm{GMP}$ and a downstream oligonucleotide. This simple experiment indicated that incubation of nematode

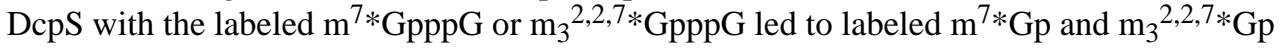
cap-derived products, respectively, as illustrated by TLC and autoradiography (Fig. 2).

In conclusion we have developed a simple and short method for specific labeling of monoand trimethylated caps with ${ }^{13} \mathrm{C}$ and ${ }^{14} \mathrm{C}$ isotopes. The compounds will be extremely useful as tools for NMR studies $\left({ }^{13} \mathrm{C}\right)$, for monitoring chemical and enzymatic reactions $\left({ }^{14} \mathrm{C}\right)$, or to synthesize RNA containing the ${ }^{14} \mathrm{C}$ labeled cap structures by in vitro transcription.

\section{Acknowledgments}

This work was partially supported by a Grant N N301 096339 from the Ministry of Science and Higher Education, Poland and Grants R0149558 and AI080805 from National Institutes of Health, USA. (to R.E.D.). We thank Dr Weizhi Liu for providing DcpS enzymes and members of the Davis lab for their help with the DcpS assays. We are also grateful to Prof. Darzynkiewicz for all kind of support.

\section{References and notes}

1(a). Furuichi Y, Shatkin AJ. Adv. Virus Res. 2000; 55:135. [PubMed: 11050942] (b) Topisirovic I, Svitkin YV, Sonenberg N, Shatkin AJ. WIREs RNA. 2011; 2:277. [PubMed: 21957010]

2(a). Matsuo H, Li H, McGuire AM, Fletcher CM, Gingras A-C, Sonenberg N, Wagner G. Nat. Struct. Mol. Biol. 1997; 4:717.(b) Marcotrigiano J, Gingras A-C, Sonenberg N, Burley SK. Cell. 1997; 89:951. [PubMed: 9200613] (c) Cai A, Jankowska-Anyszka M, Centers A, Chlebicka L, Stepinski J, Stolarski R, Darzynkiewicz E, Rhoads RE. Biochemistry. 1999; 38:8538. [PubMed: 10387101] (d) Niedzwiecka A, Marcotrigiano J, Stepinski J, Jankowska-Anyszka M, WyslouchCieszynska A, Dadlez M, Gingras A-C, Mak P, Darzynkiewicz E, Sonenberg N, Burley S, Stolarski R. J. Mol. Biol. 2002; 319:615. [PubMed: 12054859]

3(a). Thomas JD, Conrad RC, Blumenthal T. Cell. 1988; 54:533. [PubMed: 3401926] (b) Liou RF, Blumenthal T. Mol. Cell. Biol. 1990; 10:1764. [PubMed: 2157142] 
4(a). Van Doren K, Hirsh D. Mol. Cell. Biol. 1990; 10:1769. [PubMed: 1690851] (b) Maroney PA, Hannon GJ, Nilsen TW. Proc. Natl. Acad. Sci. U.S.A. 1990; 87:709. [PubMed: 2300557]

5(a). Darzynkiewicz E, Stepinski J, Ekiel I, Haber D, Sijuwade T, Tahara SM. Nucleic Acids Res. 1988; 16:8953. [PubMed: 3174438] (b) Wallace A, Filbin ME, Veo B, McFarland C, Stepinski J, Jankowska-Anyszka M, Darzynkiewicz E, Davis RE. Mol. Cell. Biol. 2010; 30:1958. [PubMed: 20154140]

6(a). Lall S, Friedman CC, Jankowska-Anyszka M, Stepinski J, Darzynkiewicz E, Davis RE. J. Biol. Chem. 2004; 279:45573. [PubMed: 15322127] (b) Cheng G, Cohen L, Mikhli C, JankowskaAnyszka M, Stepinski J, Darzynkiewicz E, Davis RE. Mol. Biochem. Parasitol. 2007; 153:95. [PubMed: 17391777]

7(a). Jankowska-Anyszka M, Lamphear BJ, Aamondt EJ, Harrington T, Darzynkiewicz E, Stolarski R, Rhoads RE. J. Biol. Chem. 1998; 273:10538. [PubMed: 9553113] (b) Keiper BD, Lamphear BJ, Deshpande AM, Jankowska-Anyszka M, Aamodt EJ, Blumenthal T, Rhoads RE. J. Biol. Chem. 2000; 275:10590. [PubMed: 10744754]

8. Liu W, Zhao R, McFarland C, Kieft J, Niedzwiecka A, Jankowska-Anyszka M, Stepinski J, Darzynkiewicz E, Jones DNM, Davis RE. J. Biol. Chem. 2009; 284:31333.

9. Miyoshi H, Dwyer DS, Keiper BD, Jankowska-Anyszka M, Darzynkiewicz E, Rhoads RE. EMBO J. 2002; 21:4680. [PubMed: 12198170]

10. Liu W, Jankowska-Anyszka M, Piecyk K, Dickson L, Wallace A, Niedzwiecka A, Stepinski J, Stolarski R, Darzynkiewicz E, Kieft J, Zhao R, Jones DNM, Davis RE. Nucleic Acids Res. 2011; 39:8820. [PubMed: 21965542]

11. Rutkowska-Wlodarczyk I, Stepinski J, Dadlez M, Darzynkiewicz E, Stolarski R, Niedzwiecka A. Biochemistry. 2008; 47:2710. [PubMed: 18220364]

12. Burgess K, Cook D. Chem. Rev. 2000; 100:2047. [PubMed: 11749283]

13(a). Fukuoka K, Suda F, Suzuki R, Takaku H, Ishikawa M, Hata T. Nucleosides Nucleotides. 1994; 13:1557.(b) Stepinski J, Bretner M, Jankowska M, Felczak K, Stolarski R, Wieczorek Z, Cai AL, Rhoads RE, Temeriusz A, Haber D, Darzynkiewicz E. Nucleosides Nucleotides. 1995; 14:717.

14. General procedure for a synthesis of $\mathrm{m}^{7} * \mathrm{GpppG}$ cap analogues labeled with ${ }^{13} \mathrm{C}$ or ${ }^{14} \mathrm{C}$. GpppG was prepared by coupling of imidazolide derivative of guanosine $5^{\prime}$-monophosphate (GMP) (21 $\mathrm{mg}, 0.05 \mathrm{mmol})$ with guanosine $5^{\prime}$-diphosphate $(27 \mathrm{mg}, 0.05 \mathrm{mmol})$ in anhydrous conditions in the presence of $\mathrm{ZnCl}_{2}(50 \mathrm{mg}, 0.37 \mathrm{mmol})$ as previously described. ${ }^{13} \mathrm{GpppG}(20 \mathrm{mg}, 0.02 \mathrm{mmol})$ was further methylated with appropriate methyl iodide, labeled with ${ }^{13} \mathrm{C}$ or ${ }^{14} \mathrm{C}(0.04 \mathrm{mmol})$ in anhydrous DMSO at room temperature for $2 \mathrm{~h}$. The reaction mixture was poured into water and extracted three times with diethyl ether. Aqueous phase was purified on DEAE-Sephadex using a $0-0.8 \mathrm{M}$ gradient of TEAB. Final products were obtained as colorless crystals $\left(\left[{ }^{13} \mathrm{C}\right] \mathrm{m}^{7} * \mathrm{GpppG}\right.$, (1) $8.4 \mathrm{mg}, 0.01 \mathrm{mmol}, 52 \%,\left[{ }^{14} \mathrm{C}\right] \mathrm{m}^{7} * \mathrm{GpppG}$, (2) $\left.7.8 \mathrm{mg}, 0.0096 \mathrm{mmol}, 48 \%\right)$; [ $\left.{ }^{13} \mathrm{C}\right]$ $\mathrm{m}^{7} *$ GpppG MS-ESI: $\mathrm{m} / \mathrm{z}$ calcd. 804.1024, Found: 804.1183; ${ }^{1} \mathrm{H}$ NMR $\left(\mathrm{D}_{2} \mathrm{O}, 500 \mathrm{MHz}\right) \delta 8.03(\mathrm{~s}$, 1H; H-8, G), 5.91 (d,1H; H-1', m7G), 5.82 (d, 1H; H-1' , G), 4.67 (t, 1H, H-2', G), 4.51-4.48 (m, 2H; H-2', m7G; H-3', G), 4.43-4.35 (m, 4H; H-3', m7G, H-4', G, H-4' , m7G, H-5' , G), 4.32-

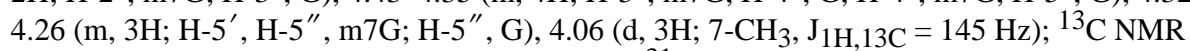
$\left(\mathrm{D}_{2} \mathrm{O}, 125 \mathrm{MHz}, \mathrm{H} 1 \mathrm{decouple} 500 \mathrm{MHz}\right) \delta 36.24 ;{ }^{31} \mathrm{P}$ NMR $\left(\mathrm{D}_{2} \mathrm{O}, 202 \mathrm{MHz}\right) \delta-10.31(1 \mathrm{P}, \mathrm{a}),-$ $10.40(1 \mathrm{P} \gamma),-21.91(1 \mathrm{P}, \beta)$.

15. Jemielity J, Stolarski R, Darzynkiewicz E. Nucloesides, Nucleotides, Nucleic Acids. 2007; 26:1315.

16. $N^{2}$-fluoro-2 $2^{\prime}, 3^{\prime}, 5^{\prime}$ - $O$-triacetyl- $O^{6}$-[2-(4-nitrophenyl)ethyl]inosine (3) The $2^{\prime}, 3^{\prime}, 5^{\prime}$-tri- $O$ acetylguanosine was prepared from guanosine using acetic anhydride in the presence of triethylamine and $N, N$-(dimethylamino) pyridine using a procedure modified from Nair et al. ( $J$. Am. Chem. Soc., 1987, 109, 7223). In the next step a suspension of $2^{\prime}, 3^{\prime}, 5^{\prime}$-tri- $O$-acetylguanosine $(2.37 \mathrm{~g}, 5.8 \mathrm{mmol})$, triphenylphosphine $(2.28 \mathrm{~g}, 8.7 \mathrm{mmol})$ and 2-(4-nitrophenyl)ethanol $(1.45 \mathrm{~g}$, $8.7 \mathrm{mmol})$ in anhydrous toluene was stirred for $30 \mathrm{~min}$ and diisopropylazodicarboxylate $(1.4 \mathrm{~mL})$ was added dropwise over a period of $45 \mathrm{~min}$. The reaction mixture was kept for $12 \mathrm{~h}$ at $\mathrm{rt}$. The solvent was evaporated and the residual oil was purified by column chromatography on silica gel with chloroform to produce a pure product, $2^{\prime}, 3^{\prime}, 5^{\prime}$-tri- $O$-acetyl- $O^{6}$-[2-(4nitrophenyl)ethyl]guanosine, of yellowish crystals, $2.26 \mathrm{~g}(70 \%) .{ }^{1} \mathrm{H} \mathrm{NMR}\left(200 \mathrm{MHz}, \mathrm{CDCl}_{3}\right) \delta$ $8.17(\mathrm{~d}, 2 \mathrm{H}), 7.72(\mathrm{~s}, 1 \mathrm{H}), 7.49$ (d, 2H), 6.05-5.91 (m, 2H), 5.87-5.75 (m, 1H), $4.73(\mathrm{t}, J=6.7 \mathrm{~Hz}$, 
$2 \mathrm{H}), 4.50-4.36(\mathrm{~m}, 3 \mathrm{H}), 3.28(\mathrm{t}, 6.72 \mathrm{H}), 2.14(\mathrm{~s}, 3 \mathrm{H}), 2.09(\mathrm{~s}, 3 \mathrm{H}), 2.08(\mathrm{~s}, 3 \mathrm{H}) ; \mathrm{m} / \mathrm{z}$. calcd for $\mathrm{C}_{24} \mathrm{H}_{26} \mathrm{~N}_{6} \mathrm{O}_{10}(\mathrm{M}+\mathrm{H})^{+}:$559.1783, found: 559.1784. In the next step dry $2^{\prime}, 3^{\prime}, 5^{\prime}$-tri- $O$-acetyl- $O^{6}-$ [2-(4-nitrophenyl)ethyl]guanosine $(1 \mathrm{~g}, 1.79 \mathrm{mmol})$ in polypropylene tube under nitrogen was dissolved in anhydrous pyridine $(6.75 \mathrm{~mL}, 0.082 \mathrm{~mol})$. The tube was placed in a dry ice/ acetonitrile cooling bath $\left(-35\right.$ to $\left.-45^{\circ} \mathrm{C}\right)$ and $70 \% \mathrm{HF} /$ pyridine solution $(12 \mathrm{~mL}, 0.42 \mathrm{~mol})$ was added dropwise over a period of $5 \mathrm{~min}$ to $45 \%$ final HF. The reaction mixture was stirred for 15 min and $t$-butyl nitrite $(0.54 \mathrm{~mL}, 4.5 \mathrm{mmol})$ was added. After $1 \mathrm{~h}$, the reaction was quenched at 0 ${ }^{\circ} \mathrm{C}$ by slowly pouring the reaction mixture into an aqueous $\mathrm{K}_{2} \mathrm{CO}_{3}$ solution $(28.5 \mathrm{~g}$ in $25 \mathrm{~mL}$ of water) and then extracted three times with ethyl acetate. The organic layers were collected, dried over anhydrous $\mathrm{Na}_{2} \mathrm{SO}_{4}$ and evaporated to dryness. Purification by column chromatography using as eluate $60: 1 \mathrm{CH}_{2} \mathrm{Cl}_{2}$ : $\mathrm{MeOH}$ gave $0.85 \mathrm{~g}(85 \%)$ of product (3); TLC silica gel, $\mathrm{CH}_{2} \mathrm{Cl}_{2} / \mathrm{MeOH}$, 60:1 $R_{\mathrm{F}}=0.4 ;{ }^{1} \mathrm{H}$ NMR $\left(700 \mathrm{MHz}, \mathrm{CDCl}_{3}\right) \delta 8.21-8.15(\mathrm{~m}, 2 \mathrm{H}), 8.08(\mathrm{~s}, 1 \mathrm{H}), 7.50(\mathrm{~d}, 2 \mathrm{H}), 6.13$ $(\mathrm{d}, J=5.6 \mathrm{~Hz}, 1 \mathrm{H}), 5.82(\mathrm{t}, J=4.9 \mathrm{~Hz}, 1 \mathrm{H}), 5.60-5.55(\mathrm{~m}, 1 \mathrm{H}), 4.84(\mathrm{t}, J=6.7 \mathrm{~Hz}, 2 \mathrm{H}), 4.46-4.42$ $(\mathrm{m}, 2 \mathrm{H}), 4.38-4.36(\mathrm{~m}, 1 \mathrm{H}), 3.32(\mathrm{t}, J=6.7 \mathrm{~Hz}, 2 \mathrm{H}), 2.15(\mathrm{~s}, 6 \mathrm{H}), 2.08(\mathrm{~s}, 3 \mathrm{H}) . \mathrm{m} / \mathrm{z}$. calcd for $\mathrm{C}_{24} \mathrm{H}_{24} \mathrm{FN}_{5} \mathrm{O}_{10}(\mathrm{M}+\mathrm{H})^{+}: 562.1579$, found: 562.1581. Synthesis of ${ }^{13}$ C labeled $m_{3}{ }^{2,2,7}{ }^{*}$ Gppp $G$ (8) $\mathrm{N}^{2}$-fluoro-2', $3^{\prime}, 5^{\prime}$ - $O$-triacetyl- $O^{6}$-[2-(4-nitrophenyl)ethyl]inosine $(3,250 \mathrm{mg}, 0.45 \mathrm{mmol})$ was dissolved in $2 \mathrm{~mL}$ of aqueous solution of DMSO/AcCN/H $2 \mathrm{O} / \mathrm{Et}_{3} \mathrm{~N}$ and $\left({ }^{13} \mathrm{CH}_{3}\right)_{2} \mathrm{NH}(1.8 \mathrm{mmol})$ was added. The reaction mixture was stirred at $60^{\circ} \mathrm{C}$ for $4 \mathrm{~h}$ until the fluoronucleoside completely disappeared. After completion of the substitution reaction, 1,8-diazabicyclo[5.4.0]undec-7-ene (DBU) was added to the reaction mixture followed by the addition of $2.75 \mathrm{~mL}$ a mixture of $0.5 \mathrm{M}$ $\mathrm{NaOH}$ in $\mathrm{THF} / \mathrm{MeOH} / \mathrm{NaOH}_{\mathrm{aq}}(5: 4: 2)$. The solvent was evaporated and the residual oil was purified by column chromatography on silica gel with $\mathrm{CH}_{2} \mathrm{Cl}_{2} / \mathrm{MeOH}(6: 1)$ to produce a pure product (4) (100 mg, 56\%). $N^{2 *}, N^{2 *}$-dimethylguanosine (75 mg, $0.24 \mathrm{mmol}$ ) was in the next step phosphorylated (Tetrahedron Lett. 1967, 8, 5065) with phosphorus trichloride oxide $(100 \mu \mathrm{L})$ in trimethyl phosphate $(2.35 \mathrm{~mL})$ at $4{ }^{\circ} \mathrm{C}$ and methylated with fivefold excess of ${ }^{13} \mathrm{CH}_{3} \mathrm{I}(0.075 \mathrm{~mL}$, $1.2 \mathrm{mmol})$ in anhydrous DMSO $(0.5 \mathrm{~mL})$. The reaction mixture was poured into water $(5 \mathrm{~mL})$ and extracted three times with diethyl ether. Aqueous phase was concentrated and applied on DEAESephadex. The product was eluted using a $0-0.8 \mathrm{M}$ gradient of TEAB. $\mathrm{m}_{3}{ }^{2,2,7} *$ GMP was obtained as a colorless crystals (6) (44 mg, $0.09 \mathrm{mmol}, 60 \%)$. The ${ }^{13} \mathrm{C}$ trimethylated guanosine $5^{\prime}$ monophosphate (6) $(0.05 \mathrm{mmol}$, TEA salt) was further coupled with the imidazolide derivative of GDP $(27 \mathrm{mg}, 0.05 \mathrm{mmol})(7)$ in anhydrous DMF $(0.5 \mathrm{~mL})$ in the presence of zinc ions $(50 \mathrm{mg}$, $0.37 \mathrm{mmol})$. The reaction mixture was poured into a solution of EDTA $(110 \mathrm{mg}, 0.46 \mathrm{mmol})$ in water $(1.5 \mathrm{~mL})$, neutralized to $\mathrm{pH} 7$ by addition of $1 \mathrm{M}$ TEAB.and separated by ion-exchange chromatography on DEAE-Sephadex. Pure product (8) was obtained as plain crystals $(29 \mathrm{mg}$, $0.035 \mathrm{mmol}, 70 \%){ }^{17} \mathrm{MS}-\mathrm{ESI}: \mathrm{m} / \mathrm{z}$. calcd 834.1337, found 834.1749; ${ }^{1} \mathrm{H}$ NMR $\left(\mathrm{D}_{2} \mathrm{O}, 500 \mathrm{MHz}\right)$ $\delta 7.97(\mathrm{~s}, 1 \mathrm{H} ; \mathrm{H}-8, \mathrm{G}), 5.95\left(\mathrm{~d}, 1 \mathrm{H} ; \mathrm{H}^{-1} 1^{\prime}, \mathrm{m}^{7} \mathrm{G}\right), 5.76\left(\mathrm{~d}, 1 \mathrm{H} ; \mathrm{H}-1^{\prime}, \mathrm{G}\right), 4.55-4.52\left(\mathrm{~m}, 2 \mathrm{H}, \mathrm{H}-2^{\prime}, \mathrm{G}\right.$, $\left.\mathrm{m}^{7} \mathrm{G}\right), 4.44-4.25$ (m, 8H; H-2', H-3', H-4', H-5', H-5" $\left., \mathrm{G}, \mathrm{m}^{7} \mathrm{G}\right), 4.07$ (d, 3H; 7-CH $3, J_{1 \mathrm{H}, 13 \mathrm{C}}=$ $145 \mathrm{~Hz}), 3.10\left(\mathrm{dd}, 6 \mathrm{H}, \mathrm{N} 2-\mathrm{CH}_{3}, J_{1 \mathrm{H}, 13 \mathrm{C}}=140 \mathrm{~Hz}\right) ;{ }^{13} \mathrm{C}$ NMR $\left(\mathrm{D}_{2} \mathrm{O}, 125 \mathrm{MHz}, \mathrm{H} 1\right.$ decouple 500 MHz) $\delta 37.46,36.14 ;{ }^{31} \mathrm{P}$ NMR $\left(\mathrm{D}_{2} \mathrm{O}, 202 \mathrm{MHz}\right) \delta-10.31$ (1P, a), -10.41 (1P $\gamma$ ),- $21.93(1 \mathrm{P}, \beta)$.

17(a). Kadokura M, Wada T, Urashima C, Sekine M. Tetrahedron Lett. 1997; 38:8359.(b) JankowskaAnyszka M, Piecyk K, Samonina-Kosicka J. Org. Biomol. Chem. 2011; 9:5564. [PubMed: 21701749]

18. Cohen LS, Mikhli C, Friedman C, Jankowska-Anyszka M, Stepinski J, Darzynkiewicz E, Davis RE. RNA. 2004; 10:1609. [PubMed: 15383679] 
A

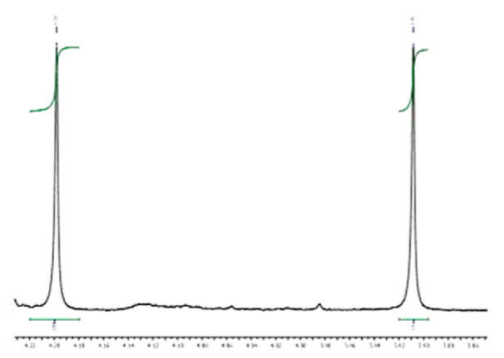

B

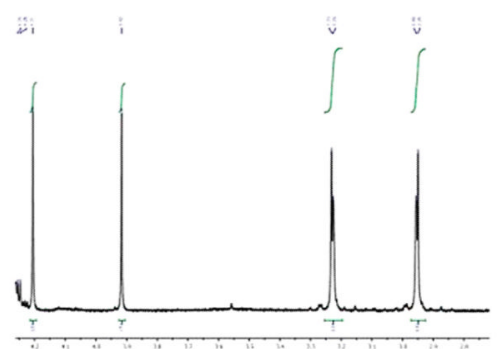

Figure 1.

Portions of the ${ }^{1} \mathrm{H}$ NMR spectra of the synthesized ${ }^{13} \mathrm{C}$-labeled MMG (A) and TMG (B) caps illustrating the characteristic ${ }^{13} \mathrm{CH}_{3}$ signals. (A) $\mathrm{N} 7{ }^{13} \mathrm{C}$ methyl group of the MMG cap, $J_{1 \mathrm{H}-13 \mathrm{C}}=145 \mathrm{~Hz}(\mathrm{~B}) \mathrm{N} 7{ }^{13} \mathrm{C}$ methyl group, $J_{1 \mathrm{H}-13 \mathrm{C}}=145 \mathrm{~Hz}$ and two N2 ${ }^{13} \mathrm{C}$ methyl groups of the TMG cap, $J_{1 \mathrm{H}-13 \mathrm{C}}=140 \mathrm{~Hz}$. 
A

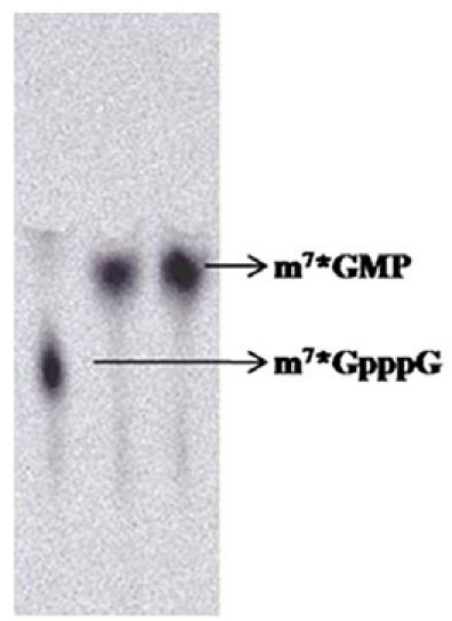

$12 \mathbf{2}$
B

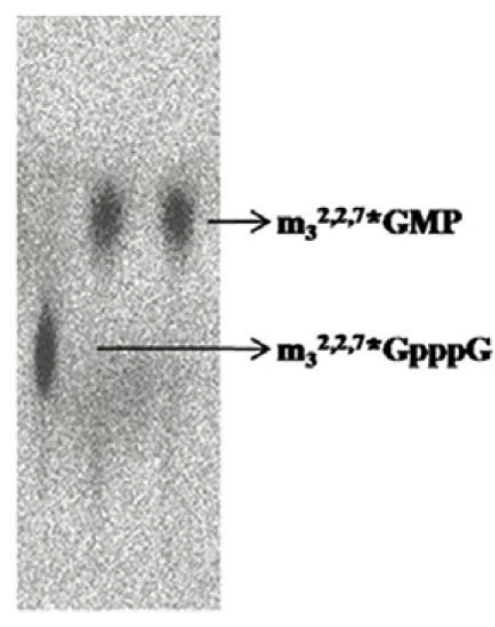

$12 \mathbf{2} 3$

Figure 2.

DcpS hydrolysis of labeled cap analogues. DcpS reactions were carried out as previously described and the labeled substrates and products were separated by PEI-cellulose thin layer chromatography (TLC), plates developed in $0.45 \mathrm{M}$ ammonium sulfate, and labeled substrate and products detected by autoradiography. ${ }^{18}$ The plates correspond to $(\mathrm{A}){ }^{14} \mathrm{C}$ labeled MMG cap, (B) ${ }^{14} \mathrm{C}$-labeled TMG cap; lane $1-{ }^{14} \mathrm{C}$ cap analogue, lane $2-{ }^{14} \mathrm{C}$ cap analogue treated with $C$. elegans $\mathrm{DcpS}$ (expressed and purified as described ${ }^{18}$ ), lane $3-{ }^{14} \mathrm{C}$ cap analogue treated with $A$. suum DcpS (GenBank Accession number (ADB92583), expressed and purified as described $\left.{ }^{18}\right)$. *indicates the position of the label. 
<smiles>Nc1nc2c(ncn2[C@H]2O[C@H](O)[C@@H](O)[C@H](O)[C@H]2O)c(=O)[nH]1</smiles>

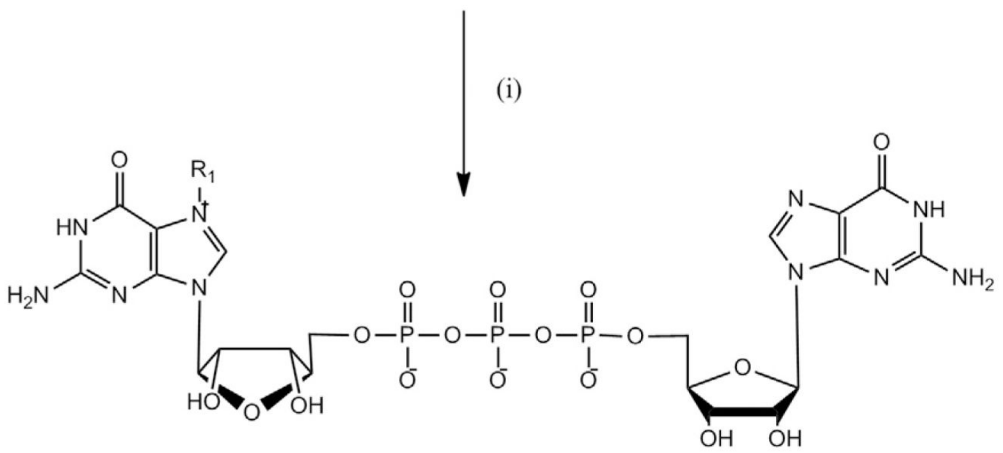

$$
\mathrm{R}^{1}={ }^{13} \mathrm{CH}_{3}(1) \text { or }{ }^{14} \mathrm{CH}_{3}(2)
$$

Scheme 1.

Synthesis of ${ }^{13} \mathrm{C}$ and ${ }^{14} \mathrm{C}$ MMG cap analogues. Reagents: (i) ${ }^{13} \mathrm{CH}_{3} \mathrm{I}$ or ${ }^{14} \mathrm{CH}_{3} \mathrm{I}$, DMSO. 

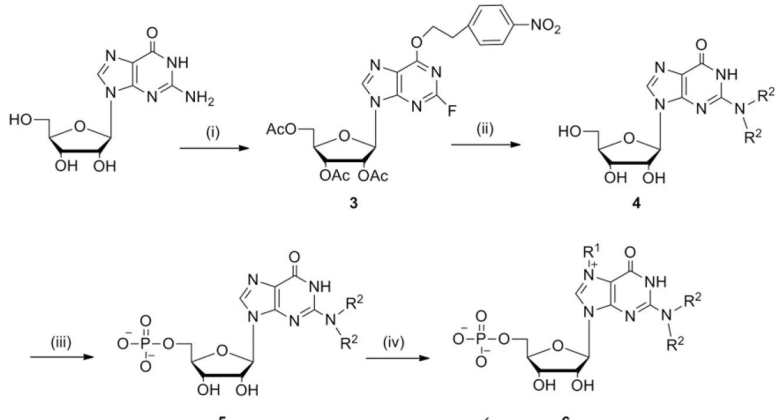

6

5
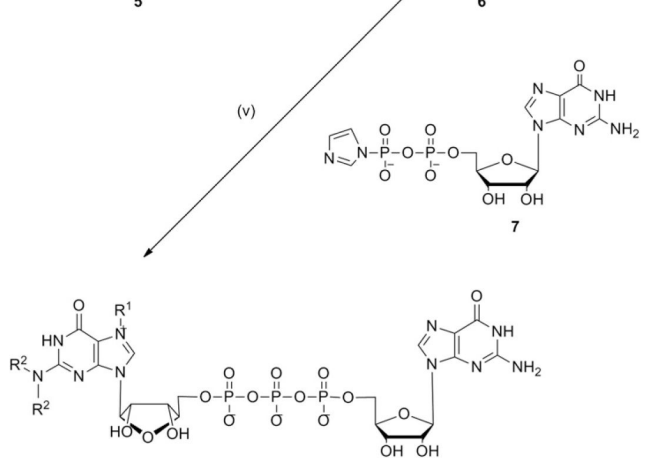

$R^{1}$ and $R^{2}={ }^{13} \mathrm{CH}_{3}$ for ${ }^{13} \mathrm{C}$ labeled TMG cap (8)

$\mathrm{R}^{1}={ }^{14} \mathrm{CH}_{3}$ and $\mathrm{R}^{2}=$ unlabelled $\mathrm{CH}_{3}$ for ${ }^{14} \mathrm{C}$ labeled TMG cap (9)

\section{Scheme 2.}

Synthesis of ${ }^{13} \mathrm{C}$ and ${ }^{14} \mathrm{C}$ TMG cap analogues. Reagents and conditions: (i) (a) acetic anhydride, DMAP, $\mathrm{Et}_{3} \mathrm{~N}, \mathrm{AcCN}, 4{ }^{\circ} \mathrm{C}$ to rt, (b) NPE, $\mathrm{PPh}_{3}$, DIAD, toluene, rt, (c) $\mathrm{HF} /$ pyridine, tBuONO, pyridine, $-40{ }^{\circ} \mathrm{C}$; (ii) (a) $\left({ }^{13} \mathrm{CH}_{3}\right)_{2} \mathrm{NH}$, DMSO/AcCN/ $\mathrm{H}_{2} \mathrm{O} / \mathrm{Et}_{3} \mathrm{~N}, 60^{\circ} \mathrm{C}$ or $\left(\mathrm{CH}_{3}\right)_{2} \mathrm{NH}$, DMSO, $60^{\circ} \mathrm{C}$, (b) THF/MeOH/NaOH aq ; (iii) $\mathrm{POCl}_{3}$, trimethylphosphate, 4 ${ }^{\circ} \mathrm{C}$; (iv) ${ }^{13} \mathrm{CH}_{3} \mathrm{I}$ or ${ }^{14} \mathrm{CH}_{3} \mathrm{I}$, DMSO, rt (v) $\mathrm{ZnCl}_{2}$, DMF. 